\title{
STUDY OF SEA ICE IN THE SOVIET ARCTIC, 1920-45
}

[Summarised from Itogi issledovaniya ledyanogo pokrova morey sovetskoy arktiki $i$ ledovyye prognozy [Results of study of ice cover in the seas of the Soviet Arctic and ice forecasts], by A. F. Laktionov. Izoestiya V sesoynznogo Geograficheskogo Obshchestva [News of the All-Union Geographical Society] (Leningrad), Tom 77, No. 6, 1945, p. 341-50. It is emphasised that this article only deals with work done by scientists of the Arctic Institute, which is one of several bodies conducting research on sea ice.]

The work on sea ice undertaken by the Arctic Institute [Arkticheskiy NauchnoIssledovatel'skiy Institut] at Leningrad and its predecessors from 1920 to $194 \overline{0}$ may be ranged under the following headings:

1. Observation of the state of the ice and compilation of summaries and navigational hand-books.

2. Study of the physical and chemical properties of sea ice.

3. Methods of ice forecasting.

1. Observation of the state of the ice and compilation of summaries and navigational hand-books

Observations on the state of the sea ice are made by polar stations, ships and aircraft. Polar stations are required to report fluctuations in the amount of ice cover; to determine the average and extreme dates of the formation of young ice, of the final freeze-up, of the break-up and of the disappearance of the ice; and to study the development of fast ice and the influence of meteorological and hydrological conditions on the growth of ice. These observations are undertaken by all polar stations on the coast, while a few stations make more detailed observations of drift and of the physical and chemical properties of ice. The number of coastal polar stations grew from five in 1920 to sixty-two in 1945; certain additional stations are manned in the navigation season only.

Observations of ice in the open sea are made by expedition ships, and also by merchantmen and icebreakers. Material collected by these ships includes reports on the strength, distribution and form of the ice encountered, and in certain cases more detailed information. The number of ships compiling such reports grew from one in 1920 to over forty in 1944. From 1938 systematic patrols along the ice edge were carried out in the navigation season; some patrols were made in winter. In order to standardise and improve the reporting of ice conditions, a number of instructions were published by the Arctic Institute. ${ }^{1-6} \dagger$

Aircraft were used for ice reconnaissance for the first time in 1929. At first they were used to inspect the ice directly ahead of a ship. Later they started systematic observation of places always found difficult for shipping, such as Proliv Vil'kitskogo (Vilkitskiy Strait). Then, as the number of available aircraft increased, a wider area was patrolled. The first winter ice reconnaissance flight was made in 1939 in the Kara Sea. From 1941 a fixed programme of such flights was carried through. As the area covered increased, the need for greater detail in reporting arose. A detailed system of notation ${ }^{7}$ to be used

$\dagger$ For references see p. 472-73. 
by the observer on his map was worked out by the Arctic Institute. In 1945 the first ice survey by aerial photography was made in a specially equipped aircraft. ${ }^{7}$ The total number of aircraft used for ice reconnaissance each year is given in the table below:

$\begin{array}{rrrr}1929 & 1 & 1937 & 8 \\ 1930 & 3 & 1938 & 19 \\ 1931 & 2 & 1939 & 22 \\ 1932 & 1 & 1940 & 24 \\ 1933 & 3 & 1941 & 26 \\ 1934 & 5 & 1942 & 11 \\ 1935 & 6 & 1943 & 17 \\ 1936 & 10 & 1944 & 11\end{array}$

Much material on the state of the sea ice in a given year, collected by polar stations, ships, and aircraft, is published in the Ledovyye Yezhegodniki [Ice Yearbooks]. In 1945 seven had been issued (for 1933-39) and three were in the press (for 1940-42). Another series, containing data on various factors affecting the ice regime, collected by polar stations over a period of years, is published under the title Vypuski po ledovym prognozam [Issues for ice forecasts]. These publications, of which thirty-two had been issued by 1945, form the basic material from which ice forecasts are made. Other important publications based on the same material are a work by A. F. Laktionov ${ }^{8}$ and ice summaries for the pilot books of all the seas in the Soviet sector of the Arctic. A series of studies of the ice conditions in specific areas, compiled by the Arctic Institute, was also prepared. ${ }^{9-14}$ Ice cover of the open sea is less fully dealt with, but D. B. Karelin ${ }^{15}$ has written a work on the Laptev Sea, N. A. Volkov ${ }^{16}$ has produced a similar work on the Chuckhi Sea and M. M. Somov ${ }^{17}$ has studied the Kara Sea.

Special study was devoted to the subject of sea ice drift. A number of works provide a physical and mathematical analysis of the drift of ice under the influence of such factors as wind and friction. ${ }^{18-22} \mathrm{~B}$. P. Berdennikov ${ }^{23}$ provided the first study of the influence of the plasticity of drifting sea ice. N. M. Storozhev ${ }^{24}$ gives a detailed analysis of ice behaviour in the south-west part of the Laptev Sea and indicates among other things the influence on that behaviour of the sea bottom in shallow waters. In another work the same author ${ }^{25}$ stresses the absence of coincidence between the phases of wind and tide on the one hand and of pressure and slackening pressure of the ice on the other. M. M. Somov ${ }^{26}$ established in the case of the Laptev Sea that the more intense the drift in winter, the less the ice cover and the thinner the ice in the following navigation season. V. Yu. Vize ${ }^{27.28}$ has written several papers on the information about drift provided by the use of buoys.

\section{Study of the physical and chemical properties of sea ice}

The study of the physical and chemical properties of sea ice was first undertaken on the voyage of the Sedov to Zemlya Frantsa-Iosifa (Franz Josef Land) in 1929 when A. F. Laktionov ${ }^{29}$ studied the variation of the salt content of sea 
ice at different temperatures and its influence on the hydrological regime of the sea. Later N. T. Chernigovskiy ${ }^{30}$ studied the penetration of radiation through ice and snow, and also the reflection factor of snow, sea ice and sea water. N. N. Kalitin ${ }^{31}$ investigated the transparence of ice to ultraviolet rays and found that ice is more permeable by diffuse than by direct radiation and that short waves penetrate it best. Study of the density of sea ice, and of its mechanical properties, was chiefly carried out at polar stations. The most detailed work in each field was done by Yu. N. Deryugin at Mys Zhelaniya and B. A. Savel'yev on Ostrov Uyedineniya. F. F. Vitman and N. P. Shandrikov ${ }^{32}$ investigated the strength of ice and defined the relationship between strength and temperature. Static and dynamic pressure of sea ice on the shore-line was first examined by I. S. Peschanskiy who provided formulae for estimating this pressure at varying temperatures. Work on the temperature of ice formed the basis of papers by Chernigovskiy and Savel'yev in which the conclusion is reached that the coefficient of heat conductivity of ice is not constant, but varies principally in accordance with variations in the composition of the air. N. N. Petrunichev ${ }^{33}$ gave a detailed method for determining the thermal balance when ice cover is present and calculated the influence of thermal changes in sea water at various levels on the growth of ice. V. I. Arnol'dAlyab'yev, ${ }^{34}$ experimenting in the Kara Sea, found that ice became stronger as the temperature went down and salinity decreased. Study of the super-cooling of sea water was carried out under both natural and laboratory conditions, in the former case by Chernigovskiy and V. Yu. Vize, in the latter by V. N. Chernysh. M. G. Golovkov ${ }^{35}$ was the first Russian to study the structure of sea ice from a petrological point of view and to distinguish between basic types of ice by their structural and textural properties. Study of the chemical properties of sea ice was carried out by a number of scientists, including Laktionov, Chernigovskiy, L. S. Borishanskiy and B. P. Bruns. They established the variations of salinity according to depth, its change due to the passage of time, the influence of temperature on salinity, and the difference in chemical composition between young, one year old and two year old ice. The gas content of ice has been the subject of another series of quantitative studies by Laktionov, Bruns, Deryugin, Arnol'd-Alyab'yev, Savel'yev, Chernigovskiy and others. Bruns has investigated the qualitative composition of these gases. The relationship between the strength of ice and the speed at which a ship can pass through it has been another subject for investigation, particularly by G. Ye. Ratmanov, Ya. Ya. Gakkel', ${ }^{36}$ Laktionov and V. V. Dremlyug. In conclusion, a general work on the results of the study of sea ice, both as a substance and as a geographical factor, is to be found in a monograph by Laktionov. ${ }^{37}$

\section{Methods of ice forecasting}

Systematic work on ice forecasting was started at the Arctic Institute in 1938. Karelin, I. M. Mamayev, Laktionov, Somov, ${ }^{38}$ Chernigovskiy and V. V. Lebe$\operatorname{dev}^{39.40}$ investigated the thickness of ice and established the relationship, in the case of fast ice, between air temperature and thickness. It then became possible to forecast in February or March the thickness that the fast ice would reach in certain areas at the time the thaw started. Another group, which 
included V. Yu. Vize, worked out empirical formulae to show the link between the break-up of fast ice on the one hand, and the temperature of the air, the thickness of the ice, and the action of the wind on the other. Regional studies of certain areas were made, showing the influence of warm currents on the break-up. Vize evolved a new method of forecasting the break-up; this, known as the "method of barometric patterns" took more factors into consideration and gave better results. The problem of predicting the formation of young ice occupied a number of people, among them Vize, Volkov, Karelin, Somov, V. S. Antonov and G. N. Smelova. Their work allows a forecast to be made, up to two months in advance for certain areas.

Methods of forecasting the extent of sea ice cover also became the subject of detailed study. Vize again did most important work. He showed that the polar anticyclone was the main factor controlling the extent of ice cover and that there was a definable link between the two. This conclusion was later confirmed by others working in the same field and the principle played a large part in the development of methods of forecasting. Vize and Karelin also examined the influence of sun spots on ice cover. B. S. Gurevich, D. A. Drogaytsev and M. M. Somov sought to show that the slow spread of unusual thermal activities from west to east along the Soviet Arctic seas was occasioned by the movement of warm waters from the Atlantic, but Vize proved that this phenomenon was caused by a circumpolar barometric wave accompanied by an atmospheric thermal wave. Study of the influence of air temperature on formation of ice cover has shown that this important factor can be used in forecasting, even though its action varies from sea to sea. The influence of compuratively warm water on ice formation was examined by M. M. Somov'1 with regard to Atlantic currents reaching the Barents and Kara Seas, by V.S. Antonov in the case of the waters of the rivers Ob' and Yenisey, and by N. A. Volkov with regard to water from the Bering Sea affecting ice in the Chukchi Sea.

Vize, Somov and G. Ya. Vangenheym succeeded in distinguishing certain laws in the succession of changes in ice cover. It is claimed that by these laws it is sometimes possible to predict the state of the ice in the navigation season on the basis of its state in the preceding winter or even autumn. As a result autumn and winter ice reconnaissance flights have been arranged in later years (immediately preceding 1945). Vize studied the circulation of the atmosphere from spring to summer and is said to have found that a reliable forecast of the ice distribution in the south-west part of the Kara Sea could be made on the basis of the intensity of the circulation of the atmosphere in that area in the spring. Forecasting the wind, a most complicated problem, is of great importance in forecasting sea ice distribution, and work in this direction has been undertaken by D. A. Drogaytsev, L. K. Baydal and A. N. Petrova.

The detailed results of all this work formed the basis of the system of ice forecasting used by the Arctic Institute in 1945. As a culminating point of this work Vize ${ }^{42}$ has written a monograph in which he makes a critical survey of existing methods and indicates a course for future development of the study of the relationship between processes in the hydrosphere and atmosphere and the ice cover of the arctic seas. 


\section{References}

A. F. Laktionov, the author of the article from which this note is summarised, indicated his references by giving in some cases the author and title of a paper, in other cases only the author's name. It has not been possible to trace all these references. For those which have been traced, bibliographical details have been given as fully as possible. The word probably before an entry indicates that Laktionov did not give the title of the paper, but from his summary of its contents it seems likely that the one given in the bibliography is the one referred to. Entries marked with an * have been verified and are most of them to be found in the library of the Scott Polar Research Institute. The Institute would welcome any identifications of untraced references.

The following abbreviations are used:

Trud. Ark. Inst. = Trudy Arkticheskogo Instituta [Transactions of the Arctic Institute]

(Leningrad). Prob. Ark.=Problemy Arktiki [Problems of the Arctic] (Leningrad).

1 *Petrichenko, A. N. Instruktsiya dlya nablyudeniy nad l'dami na polyarnykh stantsiyakh [Instructions for making observations on ice at polar stations]. Moscow, 1938.

2 *GAKkel', YA. YA. Instruktsiya dlya proizvodstoa nablyndeniy nad l'dami s korablya [Instructions for making observations on ice from a ship]. Moscow, 1938.

- Petricienko, A. N. Instruktsiya dlya proizvodstva nablyndeniy nad l'dami dlya shturmanov [Instructions for making observations on ice for helmsmen]. 1940, 1041.

- SuEsov, A. N. Instruktsiya dlya opredeleniya dreyfa l'da [Instructions for determining the drift of ice]. 1944.

s Volkov, N. A. Instruktsiya dlya opredeleniya stepeni razrusheniya l'da [Instructions for determining the degree of break-up of ice].

- Laktionov, A. F., and GakKex', Ya. YA. Al'bom ledovykh obrazovaniy [Album of ice forms]. Leningrad, Moscow, 1940.

- KAREus, D. B., and others. Ledovaya aviatsionnaya razvedka [Ice reconnaissance from the air]. Moscow, Leningrad, 1946.

- Laktionov, A. F. Atlas ledovitosti Karskogo morya [Ice allas of the Kara Sea].

- Gosoyuvov, K. A. Ledovyy pokrov vostochnoy chasti proliva Yugorskiy Shar [Ice cover of the eastern part of Proliv Yugorskiy Shar]. Trud. Ark. Inst. Tom 88, 1937, p. 7-22.

10 *Deume, N. P. Sostoyaniye l'dov v rayone Ostrovov Sergeya Kameneva [State of the ice in the region of Ostrova Sergeya Kameneva]. Trud. Ark. Inst. Tom 88, 1937, p. 23-37. [Title given by Laktionov is slightly different from title of this paper, but area covered is the same.]

11 Avtonov, V, S. Lëd bukhty Tikhoy [Ice of Bukhta Tikhaya].

12 * Laktiovov, A. F. Sostoyaniye l'dov v more, omyvayushchem severo-zapadnyye berega Zemli Frantsa-Iosifa [State of the ice in the sea washing the north-west shores of Zemlya Frantsa-Iosifa]. Trud. Ark. Inst. Tom 84, 1935, p. 45-52.

13 *Burvakiv, YE. V. Sostoyaniye ledyanogo pokrova $v$ Obskoy gube [State of the ice cover in Obskaya Guba (Gulf of Ob)]. Prob. Ark. No. 3, 1938, p. 85-92.

14 Leovov, L. I. Ledovyy rezhim proliva Sannikova [Ice regime of Proliv Sannikova].

is KA'AELIN, D. B. Ledovitost' morya Laptevykh v zavisimosti ot gidrometeorologicheskikh usloviy [The influence of hydrological and meteorological conditions on ice cover in the Laptev Sea].

10 Volkov, N. A. Ledovitost' Chukotskogo morya v zavisimosti ot gidrometeorologicheskikh usloviy [The influence of hydrological and meteorological conditions on ice cover in the Chukchi Sea].

. ${ }^{17}$ Somov, M. M. Formirovaniye ledyanogo pokrova Karskogo morya [Formation of ice cover in the Kara Sea].

18 MACHINSKIY, M. V. K teorii dvizheniya i kolebaniya ledyanogo pokrova [On the theory of movement and fluctuation of ice cover].

19 Marayev, I. II. and Petrunichev, N. M. Svobodnyy dreyf ledyanogo polya [Free drift of an ice-field].

zo Mluinayev, I. M. and Petrunichev, N. M. Primer raschëta skorosti i napravleniya dvizheniya svobodno dreyfuyushchege polya [An example in calculation of speed and direction of a freely drifting ice-field].

21 GevorkyAv, R. G. Teoriys dreyfa ledyanykh poley [Theory of drift of ice-fields]. 
22 *Gevorkyan, R. G. and Chaplygin, YE. I. Svobodnyy dreyf ledyanykh poley [Free drift of ice-fields]. Prob. Ark. No. 11, 1940, p. 5-22.

23 *BerdenNikov, B. P. O soprotivlenii ledyanogo pokrova pri vyazkom dreyfe [On the influence of plasticity in ice cover on drift]. Prob. Ark. No. 12, 1940, p. 28-41.

* Storozhev, N. M. Dreyf l'da v more Laptevykh [Drift of ice in the Laptev Sea].

2s Storozhev, N. M. Szhatiye i razrezheniye l'da [Pressure and slackening of pressure in ice].

${ }^{26}$ Somov, M. MI. Svyaz' zimnego dreyfa l'dov v moryakh sovetskoy arktiki s posleduyushchey ledovitost'yu $v$ techeniye navigatsii [The link between winter drift of ice in Soviet arctic seas and subsequent ice cover in the navigation season].

27 *VIze, V. Yu. Dreyf l'dov iz Karskogo morya v Grenlandskoye [Drift of içe from the Kara Sea to the Greenland Sea]. Prob. Ark. No. 1, 1937, p. 103-16.

as *VIze, V. Yu. O dreyfe l'dov $v$ polyarnom basseyne [On the drift of ice in the polar basin]. Zapiski Gosudarstvennogo Gidrologicheskogo Instituta [Notes of the State Hydrological Institute], (Leningrad), Vol. 10, 1933, p. 327-36.

29 *LakTionov, A. F. O nekotorykh svoystvakh morskogo l'da [On certain properties of sea ice]. This reference has not been traced, but a paper entitled $O$ svoystvakh morskogo l'da [On the properties of sea ice], by the same author on the same subject, is to be found in Trudy Instituta po izucheniyu Severa [Transactions of the Institute for the Study of the North] (Moscow), Tom 49, 1931, p. 71-96.

30 *Probably CuennigovskiY, N. T. O radiatsionnykh svoystvakh snegovogo pokrova i l'da arkticheskikh morey [On the radiative properties of the snow cover and ice of the arctic seas]. Prob. Ark. No. 6, 1939, p. 31-38.

"11 * Probably Kalitin, N. N. O prozrachnosti l'da dlya ultrafioletovoy radiatsii solntsa [On the transparence of ice to solar ultraviolet radiation]. Trud. Ark. Inst. Tom 39, 1039, p. 55-70.

32 *Probably VITMan, F. F. and Syandrikov, N. P. Nekotoryye issledovaniya mekhanicheskoy prochnosti l'da [Some investigations into the mechanical strength of ice]. Trud Ark. Inst. Tom 110, 1938, p. 83-100.

33 Petrunchev, N. N. Nekotoryye voprosy teplovogo balansa severnykh morey [Some questions of the thermal balance of northern seas].

34 *Probably Arnol'd-Alysd'yev, V. I. O prochnosti l'da Barentsova i Karskogo morey [On the toughness of the ice of the Barents and Kara Seas]. Prob. Ark. No. 6, 1939, p. 21-30.

${ }^{35}$ *Probably GoLovkov, M. P. K petrografii l'da Karskogo morya [On the petrography of the ice of the Kara Sea]. Trud. Ark. Inst. Tom 60, 1936, p. 7-39.

36 *Probably GakKeL', YA. YA. Opyt otsenki prokhodimosti l'dov na trasse severnogo morskogo puti za navigatsiyu 1933 i 1935 godov [Experiment in assessing the degree to which ice was passable for shipping on the Northern Sea Route during the navigation seasons of 1933 and 1935]. Prob. Ark. No. 1, 1937, p. 81-101.

${ }^{37}$ LaKTionov, A. F. L'dy polyarnykh morey [Ice of the polar seas].

39 *Probably Soirov, M. M. K voprosu o sredney tolshchine l'da v okrainnykh moryakh [On the question of the mean thickness of ice in the seas bordering the Arctic Ocean]. Prob. $A r k$. No. 6, 1939, p. 11-20.

39 Probably LEBEDEv, V. V. Novyye formuly rosta l'da $v$ arkticheskikh rekakh i moryakh [New formulae for the growth of ice in arctic rivers and seas]. Meteorologiya $i$ Gidrologiya [Meteorology and Hydrology], No. 6, 8, 1940, p. 40-51.

40 *Probably LeBedev, V. V. Rost l'da v arkticheskikh rekakh i moryakh v zavisimosti ot otritsatel'nykh temperatur vozdukha [Growth of ice in arctic rivers and seas under the influence of air temperatures below freezing point]. Prob. Ark. No. 5/6, 1938, p. 9-25.

¿1 *Probably Somov, M. M. O vliyanii atlanticheskikh vod na ledovyy rezhim Karskogo morya [On the influence of Atlantic waters on the ice regime of the Kara Sea]. Prob. Ark. No. 3, 1941, p. 5-13.

¿2 Vize, V. Yu. Osnovy ledovykh prognozov [Basic factors in ice forecasting]. 